\title{
Law Enforcement of Fisheries Crimes Based on the Criminal Justice System
}

\author{
Sherly Adam \\ Criminal Law Department, Faculty of Law, University of Pattimura, Ambon, Indonesia
}

\begin{abstract}
In an effort to prevent and eradicate Illegal Unreport Unregulated fisheries there are still obstacles faced by law enforcers including overlapping laws and regulations which lead to unclear which agencies are authorized to deal with fisheries issues Illegal Unreport Unregulated and facilities and infrastructure do not support supervision and law enforcement in the sea both from human resources and the technology used. For this reason, a model and strategy for law enforcement is needed that can be done in the prevention and eradication of Illegal Unreport Unregulated fisheries. This study aims to find out, analyze and find an ideal law enforcement model for the prevention and eradication of fisheries crime. The results of the study show that the ideal law enforcement model in the prevention and eradication of fisheries crime in the criminal justice system is coordination, cooperation, synchronization and transparency between the subsystems in the legal system, both legal substance (law), legal structure (law enforcement officers) and legal culture (mental attitude of law enforcement officers).
\end{abstract}

Keywords: criminal justice system, fisheries crime, law enforcement.

DOI: $10.7176 /$ RHSS/9-13-07

Publication date:July $31^{\text {st }} 2019$

\section{Introduction}

Constitutionally, the recognition of Indonesia as an archipelagic state is also contained in Article 25A of the 1945 Constitution of the Republic of Indonesia (UUD NRI) which states that "Indonesia is an archipelago characterized by an archipelago with territories and boundaries their rights are stipulated by law". The development and utilization of the potential of natural marine resources including fisheries as a national asset, in essence is a translation of the mandate of Article 33 paragraph (3) of the 1945 Constitution of the Republic of Indonesia which states "Earth and water and natural resources contained therein are controlled by the state and used for great prosperity of the people". The implementation of these constitutional provisions is based on the principles of the national economy as stipulated in Article 33 paragraph (4) of the 1945 Constitution of the Republic of Indonesia, which states that "the national economy is held based on economic democracy with the principle of togetherness, efficiency, justice, sustainability, environmentalism, independence and by maintaining the balance of progress and unity of the national economy".

The new provisions in Article 33 of the 1945 Constitution of the Republic of Indonesia are primarily intended to complement the notion of "family principle" as stated in Article 33 paragraph (1) with the principles of togetherness, efficiency, fairness, sustainability, environmental insight, independence and by maintaining a balance of progress and national economic unity. The principle of kinship and the principles of the national economy are intended as very important signs (corridors) in the effort to realize economic democracy in Indonesia. This is seen as very important so that all-natural resources of the national economy are used as well as possible to bring optimal benefits to all citizens and citizens of Indonesia.

Based on the mandate of the constitution, natural resources including fisheries must be managed in such a way that they can improve people's welfare. This is stated in the consideration of Law No. 31 Year 2004 concerning Fisheries, which among other things states that "Waters which are under the sovereignty and jurisdiction of the Republic of Indonesia and the Indonesian Exclusive Economic Zone and high seas are based on international provisions, contain fish resources and potential fish breeding land, which is mandated by the Indonesian people who have the Pancasila philosophy of life and the 1945 Constitution of the Republic of Indonesia, to be utilized to the greatest extent for the welfare and prosperity of the Indonesian people". The consideration formula reinforces the constitutional mandate so that fisheries resources are managed for the welfare of the people, and at the same time their sustainability is also maintained.

The constitutional mandate and the formulation of the above considerations when associated with the right to use, conservation, management and preservation of fish resources raises philosophical problems that the state (government) that controls natural resources including fisheries must be responsible for protecting, 
developing and preserving them as God's gift to prosper the people as mandated by paragraph IV of the Opening of the 1945 Constitution of the Republic of Indonesia.

Indonesia as an archipelago with a large part of its territory consisting of sea, has a very large and diverse fisheries potential. The potential of fisheries owned is economic potential that can be utilized for the future of the nation, as the backbone of national development. Optimal utilization is directed at the utilization of fish resources by taking into account the existing carrying capacity and sustainability to improve people's welfare, where the number of fishermen depend on fishing activities, animal protein needs for humans, increase fisheries potential, increase state income from foreign exchange, provide expansion and employment opportunities, increasing productivity, added value, and competitiveness of fishery products, as well as ensuring the sustainability of fish resources, fish cultivation and spatial planning. Nowadays, people are unwittingly destroying the marine environment through waste discharged into the sea. Garbage from food, beverage, and daily life is a lot of garbage, unfortunately, a lot of garbage, not just a lot of waste, but also a lot of things to do. environment. This if left unchecked, the survival of fish and other marine biota will be disrupted, and the existing marine resources will not be able to meet the needs of future generations.

This means that the use of fisheries resources must be balanced with it carrying capacity and fisheries resources should be able to contribute greatly to improving the welfare of the community, so that it is expected to provide continuous benefits. One of them is done by controlling fisheries business through fisheries management arrangements, but fisheries management has not been maximized due to the large number of illegal theft and fishing.

In an effort to eradicate IUU fisheries there are still obstacles faced by law enforcers including overlapping laws and regulations which lead to the lack of clarity on which agencies have the authority to deal with IUU fisheries issues and facilities and infrastructure that do not support supervision and enforcement of the law from human resources and technology used. For this reason, a law enforcement strategy that can be implemented in the prevention and eradication of IUU fisheries is needed.

It is increasingly recognized that the sea in addition to functioning as a link between one region and another in facilitating transportation relations, also the wealth contained in it greatly supports the lives and lives of many people. But with the potential of existing wealth can cause a disaster if in its management without regard to natural capacity limits.

The extent of the area and the magnitude of the potential contained can lead to various violations in the sea which hamper fisheries, some problematic activities related to law enforcement in the fisheries sector include illegal fishing, fishing with the use of materials that are harmful to marine ecosystems etc.

Sea is one of the sources of wealth of a country, because it saves natural resources very much, it is fish, seaweed, rocks, coral, and others. One of the lucky countries associated with the marine area is Indonesia. As the largest archipelagic country in the world, Indonesia has enormous marine potential. But so far, the potential of the sea has not been utilized properly in improving the welfare of the nation in general and the income of the country in particular. Even most of the results of the use of the sea have been "run" or "stolen" abroad by foreign fishermen who have modern equipment and operate to Indonesian waters illegally. In this context the maximum use of the Indonesian sea is not only appropriate but also a necessity.

Some coastal areas in Indonesia have quite high potential and strategic fishing areas so that inevitably the main livelihood for the people who live mainly in coastal areas is by fishing. The problem of illegal fishing by foreign vessels is actually not a new problem, and also not just a matter of Indonesia. Almost all countries that have marine areas experience similar problems (Canada, Chile, Argentina, Pacific Counties and so on). This problem is estimated to have occurred for quite a long time in Indonesia, but attention towards it has not been fully given the absence of institutions/departments that specifically deal with this problem in the old government. With the formation of the Ministry of Marine Affairs and Fisheries and the issuance of Decree 10 Year 2003 concerning Licensing of Fishing Businesses the policy of foreign vessels began to receive serious attention. But as with other regulations, this Decree is inseparable from the pros and cons and the possibilities of negative excesses that arise in its implementation.

On the other hand, there are several issues in fisheries development that need to get the attention of all parties, both the government, the community, and other parties related to fisheries development. These issues, including the existence of symptoms of overfishing, fishing theft, and other actions that not only cause harm to the country, but also threaten the interests of fishermen and fish cultivators, industrial climate and national 
fisheries. These problems must be resolved seriously so that law enforcement in the field of fisheries becomes very important and strategic in order to support the development of fisheries in a controlled and sustainable manner. The existence of legal certainty is a condition that is absolutely necessary in handling criminal acts in the fisheries sector.

Weaknesses in the management aspects of fisheries management, including the lack of a coordination mechanism between agencies related to fisheries management. Whereas in the aspect of bureaucracy, among others, the occurrence of conflicts of interest in fisheries management. Weaknesses in the legal aspects include law enforcement issues, the formulation of sanctions and jurisdiction or the relative competence of the district court against criminal acts in fisheries that occur outside the jurisdiction of the district court.

Legal protection including law enforcement is an important part of the government's responsibility to protect and preserve natural resources including fisheries, because based on the fact that Indonesia's fisheries potential data in 2015 is predicted to reach 13.82 million tons. This amount does not include the production potential of seaweed and non-consuming fish.

However, this has not yet been obtained in several other regions in Indonesia, which on average show a similar trend, judging from the length of ship operations for one period of arrest. Even though it is supported by abundant natural resources, especially Indonesia's fisheries potential, which in its management has been regulated in legislation especially fisheries.

The enactment of Law Number 31 Year 2004 concerning Fisheries, which was later amended by Law Number 45 Year 2009 concerning Fisheries, means that there are good intentions from the government to enforce the law in the fisheries sector, but this intention has not been fully carried out by law enforcement officers. the law is granted authority.

Law enforcement in the fisheries sector is very important and strategic in order to support fisheries development individually despite and in accordance with the principles of fisheries management so that the development of fisheries can run sustainably, therefore, the existence of legal certainty is a condition that is absolutely necessary. In Law Number 31 Year 2004 concerning Fisheries provides clarity and legal certainty regarding law enforcement for criminal acts in the field of fisheries, which includes investigations, prosecutions and examinations at the court. Thus, it needs to be specifically regulated regarding the authority of investigators, public prosecutors and judges in handling criminal acts in the fisheries sector.

The implementation of law enforcement activities in the sea essentially consists of two fields of activities that can be selected and these activities are sequentially "polical fields" and "fields of investigation" (judicial). In the polisional field carried out with daily sea operations/sea security, namely control/supervision of compliance with national legislation in the sea if in the sea operation found violations of national law, the case is resolved by investigating, which includes judicial field activities. The task of investigating at sea as part of the implementation of law enforcement in waters in the Indonesian national jurisdiction is a judicial act that has an important role, because only through the investigation process can it be believed that criminal acts have occurred, both violations and crimes that occur at sea, which are stage activities preliminary examination, to be continued at the further examination stage, that is to be prosecuted and tried before a court hearing.

The handling of the two fields of law enforcement activities in the sea above has not been established as expected, namely the implementation of controlled and integrated law enforcement activities in the sea, because it turns out in each practice that law enforcement officials from the departments/agencies individually carry out their activities. There are only according to technical authority based on statutory provisions that apply sectorally in the duties of the relevant department/agency, and there are also those that exceed the sectoral technical authority limits which cause clashes, confusion and overlap in the implementation of law enforcement at sea.

Such a situation is very unfavorable in the context of achieving the goal of legal order and legal certainty in the sea. The main obstacles in the implementation of law enforcement in the sea until now still revolve around psychological problems, because among others:

1. Each department/agency apparatus adheres to the juridical basis of legislation which until now is still valid which gives each authority a sectoral view and does not review it in an integrated national manner.

2. Interpretation of each agency on the legal basis between one another does not meet each other. 
3. The existence of expressions about the main investigator, independent investigator or sole investigator in investigative activities that are not in accordance with the use of such expressions in the provisions of criminal procedural law (Criminal Procedure Code).

4. Lack of understanding of one of the principles of national development by law enforcement officials themselves as Indonesian citizens, namely the principle of legal awareness that gives limitations that every Indonesian citizen must always be aware of and obey the law and the state's obligation to uphold and guarantee legal certainty.

According to Adrianty, et.al., Although giving the same authority in the case of an investigation of a criminal offense in the fisheries sector is the result of a political compromise between the three investigating agencies. However, this political compromise is very appropriate considering that it is not possible to submit investigative authorities to only one investigating agency as a single investigator, on the grounds:

a. The implementation of the Criminal Justice System can be understood as a mechanism for the work of criminal law enforcement officials starting from the process of investigation, prosecution, hearing in court and the implementation of court decisions. These four components work together to form what is known as the "integrated criminal justice system administration" and have interdependent relationships, namely the judicial system approach to criminal justice opens the space for consultation and coordination between sub-systems.

b. To realize the Integrated Criminal Justice System and avoid fragmentation, there is a need for synchronization in the Criminal Justice System, both substance, structure and legal culture. Substantial synchronization (substantial synchronization) includes synchronization of laws and regulations relating to the Criminal Justice System, namely regarding the duties and authority of law enforcement officials and judges. For example, synchronization Law No. 8 Year 1981 concerning the Procedure Code with other regulations so that it is expected to provide a clear reference for law enforcers.

Structural synchronization in carrying out tasks and authority includes alignment in the mechanism of administering criminal justice within the framework of relations between sub-systems. In addition to police, investigations are also carried out by Civil Servant Investigators or other investigators. Therefore, there is a need for synchronization so that there is no overlap in the implementation of duties between law enforcers.

Cultural synchronization contains an effort to always live up to the views, attitudes and philosophies that thoroughly underlie the course of the Criminal Justice System. Understanding of the three frameworks for synchronizing data is very important given the magnitude of the influence of the community environment and the areas of human life on the success of achieving goals. However, to bridge the "sectoral selfishness" investigator, according to the respondent Adrianty et al, the Ministry of Maritime Affairs and Fisheries as the Ministry responsible for managing Indonesian Marine and Fisheries should be able to re-socialize Law No. 45 Year 2009 concerning changes to Law No. 31 of 2004 and the spirit behind its formation to each investigating agency so that the "sectoral selfishness" of each investigator can be eliminated.

The granting of investigative authority in investigating criminal offenses in the fisheries sector to civil servant investigator fisheries officers of Indonesian Navy, and state police officials of the Republic of Indonesia has the consequence that each investigating agency has the right to investigate criminal acts in fisheries that occur in all Indonesian territorial waters and Indonesian Economy Exclusive Zones. This consequence raises concerns about overlapping investigations in the fisheries sector. On the other hand, achieving optimal law enforcement requires alignment in the mechanisms for administering criminal justice within the framework of relations between sub-systems. Therefore, synchronization is needed so that there is no overlap in the implementation of tasks between investigators.

One of the obstacles faced in synchronizing the criminal justice system in Maluku is the separation of islands in the jurisdiction of Maluku Province so that the authority granted by various laws to overcome or prevent criminal acts in the fisheries sector in the sea area. The policy regarding criminal offenses in the field of fisheries that occur in the sea territory of the unitary state of the Republic of Indonesia, including marine areas in Maluku Province through a system approach is the main alternative to criminal law policy. 
Naturally the structure of the archipelago in Maluku Province brings negative consequences to respond to efforts to implement the criminal law enforcement system in overcoming fisheries crime occurring in the sea area. Various problems faced by law enforcement agencies in the islands far from operational control centers, both the Police, the Attorney General's Office and the Indonesian Navy and Fisheries and Marine Investigators Service in an effort to integrate criminal law enforcement systems in island-based sea areas.

Such conditions require an integrally comprehensive approach. The integration approach is considered very adequate, because an integrated law enforcement process will give birth to a complete and integrated mechanism both in terms of institutional authority and aspects of procedures that refer to the law. An integral approach in the mechanism of the current criminal law enforcement system has not been able to answer the various obstacles faced by criminal law enforcers in the framework of eradicating criminal acts that occur. Based on the explanation, the problem that will be discussed in this paper is how is law enforcement in the sea against illegal fishing? and how is the conflict of authority in the fisheries law enforcement?

\section{Research Method}

This type of research is normative legal research, using a statute approach and a conceptual approach. The data used are secondary data collected through literature study. The collected data is then analyzed qualitatively then described so that the problems discussed, and the solutions offered can be clearly illustrated in this paper.

\section{Results and Discussion}

\section{A. Law Enforcement in the Sea against Illegal Fishing}

Law enforcement in the sea based on UNCLOS 1982 provides coastal states, the right to law enforcement and the application of national laws regarding fishing in its Exclusive Economic Zone. If there is an indication of committing a violation, the coastal state may detain the foreign vessel by first informing the flag flag country then stipulating the payment of the security deposit. The UNCLOS 1982 prohibits prison sentences against violations of fishing regulations. Located in the world coral triangle area, making the Indonesian sea rich in a variety of marine biota such as fish and coral reefs. Not surprisingly, Indonesia is one of the largest fish producers in the world, including for reef fish species. As a strategic commodity, reef fishing is one of the most cultivated by our fishermen.

Many fish producing countries carry out bilateral and multilateral cooperation agreements so that they are bound by the rules of recognized fisheries organizations. If there is a violation of the rules stipulated by the fisheries organization, the state must automatically comply with the articles of the violations that have been regulated, especially relating to administrative sanctions. If violations relating to illegal fishing are carried out in the Republic of Indonesia sovereignty, both in the territorial area and in the EEZ territory, what applies is national law by still referring to international law (UNCLOS 1982) which has been ratified by Indonesia.

There are three agencies that are authorized to enforce fisheries law based on Article 73 of the Law Number 31 Year 2004 concerning Fisheries, namely the Ministry of Maritime Affairs and Fisheries (KKP), the Indonesian Navy (TNI-AL), and the Republic of Indonesia National Police. But Law No. 31 Year 2004 concerning fisheries does not regulate the division of authority clearly and does not regulate a definite mechanism of work, so that the three agencies declare that their institutions are equally authorized in enforcing fisheries law without any integrated system of implementation.

This is referred to as a conflict of authority in the handling of fisheries law because the three agencies are equally authorized to handle the same case or run on their own without the integration of the implementation system, meaning that they are equally authorized to carry out investigation and filing of Examination Minutes (BAP) and submit it to the public prosecutor. Please note that this conflict of authority is not only negative but can also be positive (both authorities). As an illustration of a negative example of conflict of authority is when the community informs at a certain coordinate point there has been an illegal arrest (without permission). The information was then conveyed to the three fisheries law enforcement agencies namely the KKP, TNI-AL and Police agencies simultaneously. The three agencies lowered their respective fleets to make arrests, and met the three in the middle of the sea. Even though there was no argument, the same action meant that there had been a material loss. This kind of authority conflict is not profitable and a solution to the solution must be sought legally. The illustration of the example of a positive conflict of authority is that the three agencies are equally authorized to make BAP and submit it to the public prosecutor. 
If it is associated with three sources of authority, namely the authority of attribution, delegation and mandate, the authority to enforce fisheries law by the three fisheries law enforcement agencies originating from Law Number 31 Year 2004 concerning fisheries is the authority of attribution. By law, the three fisheries law enforcement agencies are equally authorized to make regulatory laws. Until now the Ministry of Maritime Affairs and Fisheries is the most advanced and advanced in making regulations on regulations in order to carry out the authority to enforce fisheries law compared to the Indonesian Navy and Police. Many regulations are issued by the Ministry of Maritime Affairs and Fisheries/KKP (Institutional Regulations and Position Regulations) to cover legal actions in the enforcement of fisheries law by their institutions. As an example of the rule of law for the formation of a fleet of KKP patrol vessels equipped with weapons, legal rules regarding fishing illegal fishing vessels, mechanisms for resolving BAP filings, etc. all of which are covered by regulatory laws. The establishment of the regulation is based on Law Number 10 Year 2004 concerning the establishment of Legislation Regulations because all acts of government in the field of law enforcement must be based on the principle of legality (based on clear legal rules).

TNI-AL agencies that are authorized to enforce fisheries law are still far behind because most of the products are legal in the form of Beleidsregel, the police rule, not regulatory laws. Policy rules have no legal force. Some of the weaknesses of policy regulations, among others:

a. The type of policy regulation is not known in the hierarchy of laws and regulations as stipulated in article 7 of the Law No. 10 Year 2004. Forms of policy regulations such as Protap, telegram, juknia jukminu, circulars, official notes and others do not include decisions/decrees and is not a form of regulatory law.

b. Institutions that issue policy regulations do not have the authority to make statutory regulations even though the Indonesian Navy as an institution that has the authority to enforce fisheries law has the same authority to form a regulation law in carrying out law enforcement authority. So, it is not in the form of a policy regulation but rather in the form of a regulatory law in the form of institutional regulations and office regulations.

c. The policy is usually used in the framework of freies ermessen meaning that government officials (public institutions) are given the authority to make rules/issue rules that are urgent because there are no legal rules that govern. So, the policy rules are only issued when urgent, while enforcement of fisheries law cannot be done urgently must be through good and mature planning.

d. The Wisdom Regulation does not have direct legal binding but still has legal relevance, meaning that this policy regulation is implemented or not implemented, does not have legal consequences or does not give birth to legal rights and obligations. The policy on the Navy's agency continues to operate because it is protected by the Military Criminal Law and the Military Discipline Law.

As an example of the regulation of the issue of the release of fishing vessels that have obtained the decision of a permanent judge based on a court decision and the execution of the release by the prosecutor's office must await approval from the Indonesian Navy. this is regulated in the policy regulations in the form of telegram letters. Actually, it violates the law, which is violating the principle of legality (every act of government must be based on law). This should be regulated in the Law because it concerns human rights.

Based on some of the weaknesses of the policy regulations, it is appropriate for the Indonesian Navy to design a fisheries law enforcement process that starts from reforming the rule of law product. If the Indonesian Navy does not start from now, it is possible that in the future the authority to enforce fisheries law will be released and transferred to more appropriate and capable institutions in enforcing fisheries law.

Judging from the history of enforcement of fisheries law, since Law Number 20 Year 1982 concerning the main provisions of the Republic of Indonesia's defense and security, actually the task of law enforcement is not the Navy's main task in Law Number 20 Year 1982 is the pattern of security enforcement, especially state sovereignty at sea.

Then it was only realized the need for additional TNI-AL main tasks in law enforcement in the sea and contained in Law No. 34 Year 2004 concerning the TNI. In the future if the task of law enforcement in the sea is not handled professionally, it is possible that the task of enforcing fisheries law will be a mere memory.

The resolution of this conflict of authority needs to be done with a legal approach. The coordination forum is determined in Article 73 paragraph (3) of Law Number 31 Year 2004 concerning fisheries and Minister 
of Maritime Affairs and Fisheries regulation No. PER. 18/MEN/2005, October 10, 2005 concerning the Coordination Forum for handling criminal acts in the fisheries sector, which has not been able to resolve the conflict of authority in the enforcement of fisheries law. Criminal subscription coordination forum in the fisheries sector has the task of coordinating criminal acts of fisheries in the fisheries sector with the following functions:

1. Coordinating criminal investigations in the fisheries sector;

2. Identify the types, modus operandi, volume and spread of criminal acts in the field of fisheries;

3. Determination of types of criminal acts in the field of fisheries that are prioritized to be processed in stages;

4. Counseling and guidance to the community to prevent criminal acts in the fisheries sector;

5. Analysis, identification and measurement of the significance of criminal acts in the fisheries sector;

6. Designing forms of coordination of activities to eradicate criminal acts in the field of fisheries;

7. Formulating and updating strategies for combating crime in the fisheries sector;

8. Monitoring and presenting reports on the implementation of criminal acts in the fisheries sector;

9. Enrichment and evaluation of the effectiveness of a criminal offense in the field of fisheries in a sustainable manner.

The membership composition of the Coordination Forum for handling criminal acts in the fisheries sector at the level of central demand (Article 5) consists of:

a. Chairperson and Minister of Maritime and fisheries Affairs;

b. Deputy chairman I by the staff of the Indonesian Navy;

c. Deputy chairman II by Head of Investigation;

d. Secretary I concurrently a member by the director General of Supervision and Control of the Data and Fisheries Sources

e. Secretary II concurrently member by assistant Operation Chief of Staff of the Indonesia Navy.

Members consist of:

a. The Attorney General for Special Crimes, the Attorney General's Office of the Republic of Indonesia;

b. Head of the Indonesian Legal and Police Development Agency;

c. Director General of Immigration in the Ministry of Justice and Human Rights;

d. Director General of Sea Transportation in the Ministry of Transportation;

e. Director General of Customs;

f. Director General of Manpower Supervision Development, Ministry of Manpower and Transmigration;

g. Director of Law and Justice, Supreme Court of the Republic of Indonesia.

The coordination forum for handling criminal acts in the field of fisheries in the regions is determined by the Governor of the provincial government and regent/mayor for the district/municipal government, while the membership of the Coordination Forum handling criminal acts in the fisheries sector consists of relevant agencies in the province or district/municipality. (Article 7 of the Regulation of the Minister of Marine Affairs and Fisheries No. PER.18/MEN/2005, dated 10 October 2005 concerning the coordination forum for handling criminal acts in the fisheries sector). For example, one of the three fisheries law enforcement agencies caught an illegal fishing vessel and the case suddenly disappeared or was frozen for no apparent reason. For this reason, there was a need for fisheries law enforcement oversight institutions and integrated implementation systems in 
handling criminal acts in fisheries. because the authority to enforce fisheries law is in sectoral agencies that are still running separately.

If it is still difficult to establish a fisheries law enforcement system in an integrated manner with an online integrated system, it is necessary to think about the establishment of separate supervision institutions based on laws and direct accountability reports to the Indonesian Parliament for all regions in Indonesia and DPRD for provincial and district/city reporting. With the existence of a supervisory institution to enforce fisheries law, the interests of the people will be protected. relating to:

In view of the current and future developments in fisheries, Law No. 31 Year 2004 regulates matters

a. fisheries management is carried out based on the principles of benefit, fairness, partnership, equity, integration, openness, efficiency, and sustainable sustainability;

b. fisheries management must be based on the principle of planning and integration of controls;

c. fisheries management is carried out by considering the division of authority between the Central Government and the Regional Government;

d. fisheries management that meets the element of sustainable development, which is supported by fisheries research and development and integrated control;

e. fisheries management by increasing education and training and counseling in the field of fisheries;

f. fisheries management supported by fisheries facilities and infrastructure as well as information systems and fisheries statistical data;

g. institutional strengthening in the field of fishing ports, fisheries transportation, and fishing vessels;

h. fisheries management which is encouraged to contribute to the development of marine and fisheries;

i. fisheries management while still paying attention and empowering small fishermen or small fish farmers;

j. fisheries management carried out in Indonesian waters, the exclusive Indonesian economic zone, and the high seas which are stipulated in the form of laws and regulations while considering applicable international standards or requirements;

k. management and utilization of fish resources, both those in Indonesian waters, exclusive Indonesian economic zones, and the high seas are controlled through the development of licensing by considering national and international interests in accordance with the capabilities of available fish resources;

1. fisheries supervision;

$\mathrm{m}$. granting the same authority in investigating criminal offenses in the field of fisheries to investigators of fisheries civil servants, TNI-AL officers and police officers of the Republic of Indonesia;

n. establishment of a fishery court; and

o. the establishment of a national fisheries development consideration board.

Based on the considerations above, then Law No. 31 Year 2004 is a renewal and improvement of regulation in the fisheries sector as a substitute for Law No. 9 Year 1985 concerning Fisheries.

\section{B. Authority Conflict in Fisheries Law Enforcement}


For this reason, the resolution of the law of conflict of authority in the enforcement of fisheries law needs to be taken from the revision of the Law Number 31 Year 2004 concerning fisheries, namely by entering a clear division of authority and equipped with a definite working mechanism and integrated fisheries law enforcement system equipped with supervisory institutions so there is no conflict of authority.

In general, the problems encountered in the islands are in the form of:

a. Understanding of the sea does not meet the true meaning. So far, the sea is seen only as a transportation medium (goods, people and services), and has not been seen and utilized as a potential that has high economic value. It is realized that sea management and utilization require high costs, so opportunities are only given to investors who have large capital, without giving access to small and medium-sized entrepreneurs to participate.

b. From an economic standpoint, activities (types and degrees) are generally limited and small scale because the average economic actors are residents of those islands who have little capital, as well as a limited market and are only located on these islands. This condition will last a long time if the government does not intervene in the fiscal transfer policy to local governments, by revising the Law Number 23 Year 2004.

c. In terms of defense security, the largest part of the territory of the island provinces has quite a number of outermost islands according to the Presidential Regulation of the Republic of Indonesia Number 78 Year 2005 concerning the management of small and outermost islands. For example, Maluku province has 19 small islands. And from a geographical point of view it is in the state border area which is the front porch of the country, so the government should take a persuasive approach (combining security and prosperity approaches) to prevent possible infiltration and intervention of foreign influences. The islands in Aru district which borders Australia are ararkula island, pananbulai island, northern cultural island, southern cultural island, coral island, enu island, rock island, meatimi arang island, panehan island and batarkusu island. Whereas the islands in Maluku regency of West Southeast bordering East Timor and Australia are Selaru Island, Larat Island, Masela Island, Leti Island, Kisar Island, Wetar Island, Lirang Island and Asutubun Island.

d. In terms of law, the regulations that have been made so far are very detrimental, because they have not been able to accommodate the interests of the island province, because fiscal transfers still use continental standards as stated in Article 14 letter d and Article 18 of the Law Number 33 Year 2004. In this context it can it was concluded that there were doubts about the statement stated in the Juanda declaration which had been fought toothily by the Indonesian government in the UNCLOS 1982 which had been ratified by the Law Number 17 Year 1985. Likewise, in Article 18 of the Law Number 32 Year 2004 concerning the withdrawal of baselines not in line with UNCLOS 1982.

e. In terms of government, the wide range of government control in the archipelago has resulted in the function of public services and supervision not running properly.

Weak coordination between law enforcement agencies can lead to overlapping authority so that it is very vulnerable to creating conflicts of interest. Uncoordinated law enforcement is one of the obstacles in eradicating IUU fisheries. Besides that, the facilities and infrastructure needed in the fisheries justice process starting from the level of investigation to the examination at the fisheries court session cost a lot.

The various authorities regulated in various laws above, indicate that the delays in resolving cases that occur in the sea area have a significant influence on the processes of criminal law enforcement. Determinants of law enforcement in the sea area in hiren include its own legal factors. Finally, the impact arises, which extends to legal uncertainty.

Legal certainty is very necessary to ensure peace and order in the community because legal certainty (general rules/provisions) has the nature of among others being forced from outside (sanctions), the nature of the law that applies to anyone. An assessment of a public policy that has an impact on many people morally. Based 
on this, Bentham found the most objective basis is to see whether a particular policy or action brings useful or useful results or otherwise disadvantages for people who are related.

The purpose of the law is the maximum welfare for the majority of the people or for all people and legal evaluation is carried out based on the consequences resulting from the process of applying the law. Based on that orientation, then the contents of the law are provisions concerning the regulation of state welfare creation.

Achieving the objectives of law requires a legal system and if it is associated with Lawrence $\mathrm{M}$. Friedman's view consists of three components, namely the component in question is the substance of law, components of legal structure and cultural components. The substance of the law is a substance component, namely the tangible results issued by the legal system. This result can be in the form of inconcreto law or the rule of special law and the rule of law in abstract or general law.

The legal structure or implementing apparatus or law enforcement is part of a legal system that operates in a mechanism, including in this component, among others, law-making institutions, courts and institutions that are authorized to implement laws and institutions authorized to act against parties which violates legal provisions.

Legal culture means the whole system of values and attitudes that affect the law. This division of the legal system into three components is to analyze the operation of a legal system or system that is operating in the study of law and society. Speaking of the legal system, it means that law is a link that has its own role, in the sense that in the legal system there are sub-systems that support each other and do not divorce between one subsystem with another sub-system. Thus, in the legal system there is still a relationship with the system outside the legal environment.

In relation to the eradication of fisheries crime there needs to be coordination and cooperation between sub-systems one with another sub-system, in this case is a sub-structure of legal structures namely police, prosecutors, judges and also supported by substance subsystems namely legislation in the region the sea, where the overlap of authority occurs in the presentation between PPNS, National Police Officers and Navy Officers, besides that it is related to the legal culture subsystem, namely the mental attitude of law enforcement officials and involved individuals who often play the law in IUU fisheries. So that it has implications in law enforcement of fisheries crime is legal uncertainty in the prevention and eradication of fisheries crime.

The ideal law enforcement must be accompanied by an awareness that law enforcement as part of the subsystem, is also a social subsystem, so that the influence of the environment on the principles of law enforcement and the principles of law that apply in civilized nations. Legal culture, as part of culture is the human attitude towards law and the legal system, which includes beliefs, values, thoughts and hopes. Human thoughts and opinions (law enforcement) are determinants of the course of the legal process. In this case, according to Siswanto Sunarso, because law is a matter of value, the legal culture is a means to use the law for the sake of upholding social norms and legal norms. Law is a social control of the government, which is a social rule and process that encourages people to behave properly to prevent bad behavior. This social control, is a network of rules and processes that are comprehensive and bring legal consequences to certain behaviors, which will have an impact on the creation of a legal culture.

In addition, the impact on law enforcement in the archipelago is the separation of islands by the sea. Considering the impact that arises on the operation of the institutional system and its legal system in the criminal law enforcement system is a concern that must receive the attention of the government. The separateness of law enforcement agencies in the archipelago region has influenced its institutional coordination and functional coordination. Such conditions are experienced by law enforcers in the field in order to anticipate new forms of crime such as corruption, illegal fishing, illegal logging, terrorism and others.

Accountable law enforcement can be interpreted as an effort to implement law enforcement that can be accounted for to the community, nation and state which concerns legal certainty in the applicable legal system. The process of law enforcement cannot be separated from the legal system itself. Legal systems can be interpreted as parts of interdependent processes and must be upheld and obeyed by law enforcers in order to enforce legal certainty.

The ideal law enforcement model in eradicating criminal acts in the fisheries sector in the criminal justice system is coordination, cooperation, synchronization and transparency between the subsystems in the legal system, both legal substance (law), legal structure (law enforcement officers) ) and legal culture (mental attitude of law enforcers) in eradicating IUU fisheries, because if there is no coordination of cooperation and 
transparency, sectoral egos will emerge from each institution that will hinder the process of solving criminal cases in the fisheries sector and cause legal uncertainty.

A conflict can occur anytime and anywhere, without being predictable by anyone, the conflict can occur because of an incompatibility between expectations and realities that occur, besides that conflict can also occur due to misunderstandings among legal subjects, or the existence of disagreement between a certain object, where the legal subjects have an interest in it. For this reason, coordination, cooperation and transparency are needed between law enforcers in eradicating criminal acts in the fisheries sector so that they can resolve IUU fisheries cases based on procedures and case audits in fisheries laws and based on the Criminal Procedure Code so that legal certainty can be realized in law enforcement. criminal offense in the field of fisheries. Besides that, it needs to improve the ability of human resources, especially at the level of education, prosecution and court so that the process of resolving and enforcing the law on IUU fisheries can be done professionally and on target so that the realization of an integrated criminal justice system in combating crime in the fisheries sector can be achieved.

In order to lead to the ideals of Indonesia as the world's maritime axis, the Ministry of Maritime Affairs and Fisheries and related institutions are committed to law enforcement at sea. The development of marine and fisheries for the next five years must be based on three pillars that are mutually integrated, namely aspects of sovereignty, sustainability, and prosperity.

To realize Indonesia as the world's maritime axis in carrying out law enforcement that is authoritative and firm, and indiscriminately (non-discriminatory). need for coordination, cooperation, synchronization, transparency so that it can realize ideal law enforcement in the prevention and eradication of Illegal Unreported and Unregulated Fishing so that optimal law enforcement can be achieved against criminal acts in the fisheries sector based on the criminal justice system, thus legal certainty and a sense of community justice. can be achieved well.

\section{Conclusion and Recommendation}

The ideal law enforcement model in eradicating criminal acts in the fisheries sector is the existence of coordination, cooperation and transparency between the sub-systems in the legal system both legal substance (law), legal structure (law enforcement officers) and legal culture (attitudes mentality of law enforcement officials) because if there is no coordination, cooperation will arise sectoral ego from each institution that will hinder the process of solving criminal cases in the fisheries sector and cause legal uncertainty. Therefore, there should be coordination, cooperation and transparency between law enforcers in eradicating criminal acts in the fisheries sector so that they can resolve IUU fisheries cases based on procedures and case checks in fisheries laws and based on the Criminal Procedure Code so that legal certainty can be realized in criminal law enforcement in the fisheries sector.

\section{References}

Abd. Asis, et.al., Strategic policy of the Government of Indonesia In the Field of Maritime and Fisheries Affairs, International Journal of Scientific and Research Publications, Volume 6, Issue 12, December 2016.

Abd. Asis, et.al., Hak-Kewajiban Nelayan dan Kelompok Nelayan Menurut UU RI Nomor 7 Tahun 2016, Jurnal Hukum "Justitia" Vol. V. No. 1 September 2017.

Abd. Asis, et.al., Persoalan Hukum Nelayan dan Kelompok Nelayan di Kabupaten Takalar, Jurnal Ilmu Hukum "The Juris" Vol. II No. 2 December 2018.

Adrianty, et.al., Harmonisasi Penegakan Hukum Antara Penyidik dan Penuntut Umum Dalam Tindak Pidana Perikanan di Indonesia, Jurnal Penelitian Hukum, Analisis, June 2012, Vol. 1, No. 1.

Akhmad Fauzi, Kebijakan Perikanan dan Kelautan Issue, Sintesis dan Gagasan, PT Gramedia Pustaka Utama, Jakarta, 2005.

Djoko Pramono, Budaya Bahari, PT Gramedia Pustaka Utama, Jakarta, 2005.

Fifth National Law Seminar in 1990 (Book I), National Legal Development Agency of the Ministry of Justice, 1991. 
Kadarudin, Potensi Indonesia Menjadi Protecting Power dalam Memberikan Good Offices Terhadap Penyelesaian Konflik Internasional, Jurnal Hukum “Justitia”, Vol. II No. 1 September 2014.

Kadarudin, State Commitment to Fights Sea Pollution by Plastic Waste in United Nations Convention on Climate Change, Jurnal Ilmu Hukum “The Juris” Vol. II No. 1 June 2018.

Lili Rasjidi and I. B. Wyasa Putra, Hukum Sebagai Suatu Sistem, Remaja Rosdakarya, Bandung, 1983.

Muhadar, et.al., Penegakan Hukum Tindak Pidana Lingkungan Hidup Dalam Bidang Perikanan (Studi kasus di Kabupaten Pangkajene Kepulauan), Jurnal Penelitian Hukum, Volume 2 Nomor 1 september 2012, Fakultas Hukum Universitas Hasanuddin, Makassar, 2012.

P. Joko Subagyo, 1993, Hukum Laut Indonesia, Rineka Cipta, Jakarta, 1993.

Peter Mahmud Marzuki, 2005, Penelitian Hukum, Prenadamedia Group Jakarta.

R. Soeroso, Pengantar Ilmu Hukum, Sinar Grafika, Jakarta, 1993.

Siswanto Sunarso, Hukum Pidana Lingkungan Hidup dan Strategi Penyelesaian Sengketa, PT Rineka Cipta, Jakarta, 2005.

Soni Keraf, Etika Bisnis Tuntutan dan Relevansinya, Kanisius, Yogyakarta, 1998.

Sudikno Mertokusumo, Mengenal Hukum Suatu Pengantar, Liberty, Yogyakarta, 1996. 